\title{
WHEAT YIELD PERFORMANCE AS INFLUENCED BY DEFICIT IRRIGATION
}

\author{
M. H. Hassan ${ }^{1}$, E. A. El-Metwally ${ }^{2}$, \\ N. Z. Aboelfotoh ${ }^{3}$ and A. Hassan ${ }^{4}$.
}

\begin{abstract}
Two field experiments were performed in 2010-2011 and 2011-2012 winter seasons at two sites at Agricultural Experimental Station (AES) in Giza and at Wadi El-Natron Experimental Station (WES), Faculty of Agriculture, Cairo University for studying the effect of three water deficit levels [10\%, 20\% and 30\% (ETc) Crop Evapotranspiration] at different growth stages of wheat (vegetative, flowering, repining, mature stage and all growth stages combined), crop response factor to deficit irrigation (Ky) and impact of deficit on water productivity. The reduction percentage of seed-wheat yield was 13.6, 10.2, 7.2, 3.7 and $3.6 \%$ when deficit irrigation was applied in (AES) at all growth stages combined, flowering, repining, vegetative and mature stage respectively. Whereas, the reduction percentage was 14.1, 12.2, 8.2, 12.2 and 5.7\% for the same treatments in (WES). The yield response factor (Ky) values increased by increasing the deficit level. Crop response to deficit irrigation (ky) according to the different stressed-growth stages is found in the following order flowering > repining > mature> overall season> vegetative in both sits under studied conditions.
\end{abstract}

\section{INTRODUCTION}

7 o sustain the rapidly growing world population, agricultural production will need to increase (Howell, 2001). Hence,

1 sustainable methods to increase crop water productivity are gaining importance in arid and semi-arid regions (Debaeke and

\footnotetext{
${ }^{1}$ Prof., Agric. Eng. Dept., Fac. of Agric., Cairo Univ.

${ }^{2}$ Prof., Agro. Dept., Fac. of Agric., Cairo Univ.

${ }^{3}$ Prof., water management research institute.

${ }^{4}$ Doministraror., Agric. Eng. Dept., Fac. of Agric., Cairo Univ.
} 
Aboudrare, 2004). Traditionally, agricultural research has focused primarily on maximizing total production. In recent years, focus has shifted to the limiting factors in production systems, notably the availability of either land or water. Within this context, deficit irrigation has been widely investigated as a valuable strategy for dry regions (Fereres and Soriano, 2007). Deficit evapotranspiration is among the techniques of increasing effective use of water. Crops are exposed to water stress up to certain degree either throughout the entire growth season or at certain growth stages. In other wards deficit irrigation aims at stabilizing yields and at obtaining maximum water productivity (WP) rather than maximum yields (Zhang and Oweis, 1999). Mugabe and Nyakatawa (2000) observed that applying $75 \%$ and $50 \%$ of crop water requirements resulted in wheat yield decreases of $12 \%$ and $20 \%$ in 2 years, respectively. Kirda et al. (1999) found that deficit irrigation treatments revealed that grain yield of winter wheat was sensitive to water stress during different growth development stages. The sensitivity of grain yield to water stress was greatest when irrigation deficit was imposed during the booting to flowering stage. From this maximum, the sensitivity decreased for other stages of development in the following order: winter afterward to booting, flowering to milking, seeding to winter forward and milking to ripening. Bazza (1999) mentioned that the grain yield deficiency resulted by deficit irrigation is due to tiller density, kernel density, number of spikelets per spike, weight of kernels and number of kernels per spike according to the stressed-growth stage. Ebrahimi Pak (2012) applyed deficit irrigation on wheat at different growth; he found that, the highest and the lowest grain yields were obtained in full irrigated and stressed flowering stage treatments, respectively. Potential evapotranspiration of wheat was $641 \mathrm{~mm}$. In general, in all plant growth stages, actual and relative yields decrease as relative evapotranspiration decreases. Singh (1981) observed that without prior ET deficit in the vegetative stage, wheat yields were sensitive to water deficit during critical booting/heading period but were relatively insensitive when the plants were conditioned to some $15 \%$ 
moisture stress in the vegetative stage. The aim of this study is evaluating the influence of different water deficits on the crop yield at different stages under different studied conditions, calculating the $\mathrm{Ky}$ (crop response factor) values and studying the impact of deficit irrigation on water productivity.

\section{MATERIALS AND METHODS}

Two field experiments were carried out at the Agricultural Experimental Stations (AES), Faculty of Agricultural, Cairo University., Giza, Egypt (Latitude $3003^{\circ} \mathrm{N}$ - Longitude $3113^{\circ}$ E) and Wadi El-Natron Experimental Station (WES) (Latitude $3030^{\circ} \mathrm{N}$ - Longitude $3020^{\circ} \mathrm{E}$ ) during two successive seasons of 2010-2011 and 2011-2012.

\section{Experimental design:}

1- In the Agricultural Experimental Stations (AES) (with clay soil and surface irrigation) (Giza), the field of study was divided into 48 equal plots. The experimental unit area was $14 \mathrm{~m}^{2}(5.0 \times 2.8)$. These plots were separated from each other by small canal ( $2 \mathrm{~m}$ width) to avoid lateral movement of irrigation water to the adjacent plots.

2- In Wadi El-Natron Experimental Station (WES) (with sandy soil and sprinkler irrigation), the field of study was divided into 48 equal plots. The experimental unit area was $100 \mathrm{~m}^{2}(10 \times 10 \mathrm{~m})$.

A split plot design with three replicates was adopted in the two experimental areas. Irrigation treatments were allocated in the main plots, while stressed growth stages were allocated in the sub-plots.

\section{Treatments:}

I -Main plots (water deficit): Three levels of irrigation water deficit were investigated in this study in addition to no stressed treatment:

- Irrigation with $90 \%$ of ETc (crop evapotranspiration) (10\% deficit irrigation)

- Irrigation with $80 \%$ of ETc (20\% deficit irrigation)

- Irrigation with $70 \%$ of ETc (30\% deficit irrigation) 
II - Sub-plots (growth stage: vegetative stage, flowering stage, ripping stage, Mature stage and all stages.

\section{Planting}

The experiments were started at the beginning December of 2010 and 2011. The planting date was $01 / 12$ and the harvest date was $20 / 5$ in both growing seasons.

\section{Planting and Fertilization rats}

Seeds rate, fertilization types, application rates and dates of application for different utilized fertilizers were applied according to recommendation of Ministry of Agriculture and land reclamation (MOALR 2002).

\section{Irrigation water application:}

- In Agricultural Experimental Station (AES) (with clay soil and surface irrigation), water was added to each plot by gated pipe (75 $\mathrm{mm}$ in diameter, its hole is $63 \mathrm{~mm}$ in diameter), and its average discharge is $2.1 \mathrm{Liter} / \mathrm{sec}$. A gate was established on the irrigation channel to achieve a constant head of water during water applications.

- In Wadi El-Natron Experimental Station (WES) (with sandy soil and sprinkler irrigation), water was added to each plot by 4 sprinklers (Full circle coverage, with Possibility of pattern adjustment). The application rate was $1.3 \mathrm{~m}^{3} / \mathrm{h}$ at 2.6 bars.

\section{Irrigation water requirements:}

Irrigation water requirements (IWRc) was calculated using CROPWAT program (According to Smith 1992) and leaching requirements are neglected. IWRc is calculated as a daily requirement and multiplied by irrigation intervals in days. Irrigation interval in (AES) was 15 days except during flowering stage it was 7 days. Whereas it was 3 days in (WES). The soil moisture content is measured before and after each growing season. 


\section{Application Efficiency (Ea)}

Water application efficiency for an irrigated area $(\mathrm{Ea})$ is the ratio expressed in percent between the volumes of water stored in root zone to the volume of water delivered to the area. Application efficiency (Ea) was calculated using the following equation (James 1988)

$$
E a=\left(100 \times \frac{V_{s}}{V_{a}}\right)
$$

Where ;

$\mathrm{Ea}=$ application efficiency

$\mathrm{Vs}=$ volume of water stored in root zone in an area;

$\mathrm{Va}=$ volume of water applied to the same area;

Finally, under the condition of these two experiments, the application efficiency was $70 \%$ with surface irrigation in clay soil in (AES) and $85 \%$ under sprinkler irrigation in sandy soil in (WES) .

\section{Soil sampling}

Undisturbed and disturbed soil samples were collected from the three investigated successive soil depths $\{0-20,20-40$, and $40-60 \mathrm{~cm})$ to determine some physical characteristics of the experimental soil site.

\section{Laboratory determinations (Physical characteristics)}

Particle size distribution, according to the International method (Klute 1986), using $\mathrm{NH}_{4} \mathrm{OH}$ as dispersing agent.

\section{Water use efficiency (Water productivity):}

Water use efficiency of crop was calculated according to Giriappa (1983) using the following equations:

$$
I W U E=\frac{\text { Yield }(\mathrm{kg} / \mathrm{fed})}{I W R c\left(\mathrm{~m}^{3} / \mathrm{fed}\right)}
$$

\section{Where:}

$$
\mathrm{ETa}=\text { actual evapotranspiration }
$$


IWRc $=$ irrigation water requirement

IWUE = irrigation water use efficiency

\section{Yield response factor}

The response of yield to water supply is quantified through the yield response factor $(\mathrm{ky})$ which relates relative yield decrease $(1-\mathrm{Ya} / \mathrm{Ym})$ to relative evapotranspiration deficit (1-ETa/ETm).Ky was calculated according to Doorenbos and Kassam (1986) as following.

$$
\left[1-\left(\frac{\mathrm{Ya}}{\mathrm{Ym}}\right)\right]=K y\left[1-\left(\frac{E T a}{E T m}\right)\right]
$$

Where:

Ya = actual harvested yield.

$\mathrm{Ym}=$ maximum harvested yield $(0 \%$ stress treatment $)$.

$1-(\mathrm{Ya} / \mathrm{Ym})=$ relative yield decrease .

$\mathrm{Ky}=$ yield response factor.

$1-(\mathrm{ETa} / \mathrm{ETm})=$ relative evapotranspiration deficit.

$\mathrm{ETa}=$ actual evapotranspiration.

$\mathrm{ETm}=$ maximum crop evapotranspiration ( $0 \%$ stress treatment $).$

\section{Field measurements}

\section{Straw and seed yields}

Straw and seed yield of wheat was obtained from a central area $1 \mathrm{~m} \times 1$ $\mathrm{m}$. of each plot to avoid the borders effect and calculated as $\mathrm{kg} / \mathrm{fed}$.

\section{Statistical analysis}

All the data were statistically analyzed following the procedure outlined by (Snedecor and Cochran, 1980) using “ASSISTAT program” in which irrigation treatment represented main plot; while stressed growing stages represented sub- main plot.The differences between the mean values were compared by Duncan's multiple, range test (1955). The curve fitting programme was used to derive the mathematical relationship for predicting the seed-yield at each deficit level 


\section{RESULTS AND DISCUSSION}

\section{Physical characteristics of the soil}

Data of soil physical characteristics at the Agricultural Experimental Station (AES) (with surface irrigation and clay soil) are presented in Table (1). Data indicate that soil texture class at the experimental site is clay loam. The particle size distribution of the Wadi El-natron Experimental station (WES)(with sandy soil and sprinkler irrigation) of the investigated site is shown in Table (2). Data indicate that soil texture class of the experimental site is sandy and homogenous along the whole studied depths of soil profile.

Table: (1): physical characteristics of the Agricultural Experimental Station (AES) (with surface irrigation and clay soil).

\begin{tabular}{cccccccc}
\hline $\begin{array}{c}\text { Soil } \\
\text { depth } \\
\text { cm }\end{array}$ & \multicolumn{2}{c}{ Particle size distribution ( \% ) } & Texture & F.C & W.P \\
\cline { 2 - 6 } & C. sand & F. sand & Silt & Clay & class & & \\
\hline $0-20$ & 1.49 & 35 & 33.3 & 30.21 & Clay loam & 38.2 & 18.4 \\
$20-40$ & 1.77 & 34.92 & 30.21 & 33.1 & Clay loam & 38.2 & 18.4 \\
$40-60$ & 0.31 & 40.92 & 29.2 & 29.57 & Clay loam & 38.2 & 18.4 \\
\hline
\end{tabular}

Table (2): physical characteristics of the Wadi El-natron Experimental station (WES)(with sandy soil ad sprinkler irrigation).

\begin{tabular}{cccccccc}
\hline \multirow{2}{*}{$\begin{array}{c}\text { Soil depth } \\
\text { cm }\end{array}$} & \multicolumn{4}{c}{ Particle size distribution ( \% ) } & Texture & F.C & W.P \\
\cline { 2 - 5 } & $\begin{array}{c}\text { C. } \\
\text { Sand }\end{array}$ & $\begin{array}{c}\text { M. } \\
\text { Sand }\end{array}$ & $\begin{array}{c}\text { F. } \\
\text { Sand }\end{array}$ & Silt+Clay & & & \\
\hline $0-20$ & 22.5 & 46.5 & 28.6 & 2.4 & Sand & 11.2 & 4.2 \\
$20-40$ & 22.9 & 46 & 28.7 & 2.4 & Sand & 11.2 & 4.2 \\
$40-60$ & 22.8 & 46.4 & 28.5 & 2.3 & Sand & 11.2 & 4.2 \\
\hline
\end{tabular}

\section{Soil moisture characteristics.}

Table (1 and 2) display the moisture characteristics of both investigated sites. The field capacity is 11.2 and 38.2 for (WES) and (AES) respectively. Whereas, the wilting point is 4.2 and 18.4 in the same order. 


\section{Electric conductivity (EC) for irrigation water.}

The total soluble salts in irrigation water are represents as electric conductivity in table (3).

Table (3): Electric conductivity (EC) for irrigation water.

\begin{tabular}{ccc}
\hline $\begin{array}{c}\text { Experimental } \\
\text { site }\end{array}$ & Water source & (EC) $\mathbf{m m h o s} / \mathbf{c m}$ \\
\hline AES & Ground water & 1.3 \\
\hline WES & Ground water & 3.6 \\
\hline
\end{tabular}

\section{Applied depth of water}

Table (4) and (5) show the depth of applied water (in $\mathrm{mm}$ ) to each treatment in (AES) and (WES). The main row represents the stressed growth stage that undergoes water deficit level presented on the main column. Mainly, this is attributed to the differences in the climatological conditions.

The total values of irrigation water requirements for wheat in (AES) range between 667 and $467 \mathrm{~mm}$. Similarly, in sandy soil, it ranged between 592 and $415 \mathrm{~mm}$ in the first season and between $690 \mathrm{~mm}$ and $483 \mathrm{~mm}$ in the second season. The applied water depth varied according to both stressed growth stage and water deficit level. The averages of applied water depths in (AES) are 652, 651, 647, 619 and $567 \mathrm{~mm}$ under water deficit during mature, flowering, repining, vegetative and all stages combined respectively. For the same stressed growth stages the averages of applied water depths in (WES) were 628, 625, 622, 594 and $545 \mathrm{~mm}$ respictively. The soil moisture content is measured before and after each growing season; but no change is found in any.

Since the saved water depths, as a result of applying deficit irrigation, have an inverse relationship with the depth of applied water, the highest saved water depth is achieved by applying deficit irrigation on all growth stages combined followed by vegetative then repining, flowering and mature stages respectively. May be this is related to the length of stressed period as the longer period the higher consumed or saved water. 
Table (4): Applied water depth in $(\mathrm{mm})$ for wheat for different stressed-growing stages under different irrigation deficits compared with non-stressed treatment in (AES) (average of two seasons)

\begin{tabular}{ccccccc}
\hline \multirow{2}{*}{$\begin{array}{c}\text { Irrigation } \\
\text { deficit }\end{array}$} & $\begin{array}{c}\text { Vegitative } \\
\text { mm }\end{array}$ & $\begin{array}{c}\text { Flowering } \\
\text { mm }\end{array}$ & $\begin{array}{c}\text { Repining } \\
\text { mm }\end{array}$ & $\begin{array}{c}\text { Matur } \\
\text { mm }\end{array}$ & $\begin{array}{c}\text { All } \\
\text { stages } \\
\text { mm }\end{array}$ & Mean \\
\hline $\mathbf{1 0 \%}$ & 635 & 656 & 653 & 657 & 600 & $\mathbf{6 4 0}$ \\
$\mathbf{2 0 \%}$ & 603 & 645 & 640 & 647 & 534 & $\mathbf{6 1 4}$ \\
$\mathbf{3 0 \%}$ & 571 & 634 & 626 & 637 & 467 & $\mathbf{5 8 7}$ \\
$\mathbf{0 \%}$ & 667 & 667 & 667 & 667 & 667 & $\mathbf{6 6 7}$ \\
Mean & $\mathbf{6 1 9}$ & $\mathbf{6 5 1}$ & $\mathbf{6 4 7}$ & $\mathbf{6 5 2}$ & $\mathbf{5 6 7}$ & \\
\hline
\end{tabular}

Table (5): Applied water in ( $\mathrm{mm}$ ) for wheat for different stressedgrowing stages under different irrigation deficits compared with non-stressed treatment in (WES).

\begin{tabular}{ccccccc}
\hline \multirow{2}{*}{$\begin{array}{c}\text { Irrigation } \\
\text { deficit }\end{array}$} & $\begin{array}{c}\text { Vegitative } \\
\text { mm }\end{array}$ & $\begin{array}{c}\text { Flowering } \\
\text { mm }\end{array}$ & $\begin{array}{c}\text { Repining } \\
\text { mm }\end{array}$ & $\begin{array}{c}\text { Mature } \\
\text { mm }\end{array}$ & $\begin{array}{c}\text { All } \\
\text { stages } \\
\text { mm }\end{array}$ & Mean \\
\hline $\mathbf{1 0 \%}$ & 610 & 630 & 629 & 632 & 577 & $\mathbf{6 1 6}$ \\
$\mathbf{2 0 \%}$ & 578 & 619 & 616 & 624 & 513 & $\mathbf{5 9 0}$ \\
$\mathbf{3 0 \%}$ & 547 & 608 & 603 & 615 & 449 & $\mathbf{5 6 4}$ \\
$\mathbf{0 \%}$ & 641 & 641 & 641 & 641 & 641 & $\mathbf{6 4 1}$ \\
Mean & $\mathbf{5 9 4}$ & $\mathbf{6 2 5}$ & $\mathbf{6 2 2}$ & $\mathbf{6 2 8}$ & $\mathbf{5 4 5}$ & \\
\hline
\end{tabular}

Seed yield

The variance between yields given from the two sits (WES < AES) may be due to the deficiency of fertility in the sandy soil in (WES) as a new land in compare with clay soil in (AES) as an old one. Furthermore, the salinity difference between the two kinds of irrigation water, climatic conditions, and the two kinds of soil may be had a role in this variation. These results agree with (Eid and Abuarab, 2013) and (Liu, 2011); as they found that the wheat yield was 7.3 ton/ha in clay soil and 5.8 ton/ha in sandy soil.

a-Effect of deficit irrigation level on seed-yield

Seed yields ( $\mathrm{Kg} / \mathrm{fed})$ of wheat crop influenced by irrigation deficit level at different stressed growth stages (AES) and (WES) as tabulated in 
Table (6) and (7). The curve fitting programme was used to derive the mathematical relationship for predicting the seed-yield at each deficit level. The obtained results indicate that seed yield of wheat crop decreases when the level of deficit irrigation increases. The wheat seedyield averages were 2641, 2479 and $2312 \mathrm{~kg} / \mathrm{fed}$ under irrigation deficit by $10 \%, 20 \%$ and $30 \%$ compared with $2734 \mathrm{~kg} / \mathrm{fed}$ under no-stress condition. Likewise, in (WES), the seed-yield averages of wheat have a similar trend as in (AES). But, generally, the yields in sandy soil were less than its counterpart in clay soil. Consequently, the seed-yield averages of wheat were 1343, 1244 and $1148 \mathrm{~kg} / \mathrm{fed}$ under irrigation deficit by $10 \%, 20 \%$ and $30 \%$ compared with $1424 \mathrm{~kg} / \mathrm{fed}$ under nostress condition.Concerning the effect of deficit irrigation on the seed yield of wheat crop, the obtained data indicate that, seed yield averages of wheat decrease with increasing deficit irrigation level, Therefore, the seed yields of wheat are found in the following order $0 \%>10 \%>20 \%$ $>30 \%$ Etc. Statistical analysis shows that seed-yield averages of wheat are significantly decreased with increasing water deficit from $10 \%$ to $20 \%$ then to $30 \%$ in the two sits. The mean values of seed-yield under different deficit irrigation levels show a significant decrease at $20 \%$ and $30 \%$ at (AES) with LSD 166.8 at 0.05 . While the $10 \%$ deficit irrigation decreases the seed-yield but not significantly. These mean that $10 \%$ is an acceptable level for applying deficit irrigation under (AES) condition. On the other hand, applying deficit irrigation in (WES) resulted in a significant decrease in seed-yield averages at the three studied levels of deficit irrigation with LSD 51.3.

\section{b- Effect of stressed-growth stage on seed-yield.}

The seed-yield averages fluctuate according to the stressed growth stages. Therefore, at (AES), the seed-yield averages were 2633, 2480, 2550, 2640 and $2406 \mathrm{Kg} /$ fed under deficit irrigation condition for vegetative, flowering, repining, mature and all growth stages combined, respectively. 
In (WES), the yield averages were 1327, 1250, 1307, 1343 and 1223 $\mathrm{Kg} / \mathrm{fed}$ under deficit irrigation circumstances for vegetative, flowering, repining, mature and all growth stages combined, respectively.

Therefore, the seed-yield averages resulted from applying deficit irrigation at different growth stages decreased according to the stressed growth stage. The data in table (6 and 7) indicate that seed-yield averages resulted from applying deficit irrigation through different growth stages followed the order of mature $>$ vegetative $>$ repining $>$ flowering $>$ all stages combined under both sits conditions.

Table (6): wheat grain yield average (Kg /fed) for different stressed-growing stages under different irrigation deficit levels compared with non-stressed treatment in (AES) (with clay soil and surface irrigation).

\begin{tabular}{|c|c|c|c|c|c|c|}
\hline \multirow[b]{2}{*}{$\begin{array}{l}\text { Irrigation } \\
\text { deficit }\end{array}$} & \multicolumn{5}{|c|}{ growth stages } & \multirow[b]{2}{*}{ Mean } \\
\hline & $\begin{array}{c}\text { Vegitative } \\
\text { kg/fed }\end{array}$ & $\begin{array}{c}\text { Flowering } \\
\text { kg/fed }\end{array}$ & $\begin{array}{l}\text { Repining } \\
\text { kg/fed }\end{array}$ & $\begin{array}{l}\text { Mature } \\
\text { kg/fed }\end{array}$ & $\begin{array}{c}\text { All } \\
\text { stages } \\
\text { kg/fed }\end{array}$ & \\
\hline \multirow{2}{*}{$10 \%$} & 2708 & 2604 & 2642 & 2714 & 2539 & 2641 \\
\hline & $\mathrm{aA}$ & $\mathrm{aAB}$ & $\mathrm{abAB}$ & $\mathrm{aA}$ & $\mathrm{bB}$ & $\mathbf{a b}$ \\
\hline \multirow{2}{*}{$20 \%$} & 2605 & 2392 & 2486 & 2611 & 2303 & 2479 \\
\hline & $\mathrm{abA}$ & $\mathrm{bBC}$ & bcAB & $\mathrm{abA}$ & $\mathrm{cC}$ & $\mathbf{b}$ \\
\hline \multirow{2}{*}{$30 \%$} & 2485 & 2191 & 2337 & 2500 & 2048 & 2312 \\
\hline & $\mathrm{bA}$ & $\mathrm{cBC}$ & $\mathrm{cAB}$ & $\mathrm{bA}$ & $\mathrm{dC}$ & c \\
\hline \multirow{3}{*}{$0 \%$} & 2734 & 2734 & 2734 & 2734 & 2734 & 2734 \\
\hline & $\mathrm{aA}$ & $\mathrm{aA}$ & $\mathrm{aA}$ & $\mathrm{aA}$ & $\mathrm{aA}$ & $\mathbf{a}$ \\
\hline & $\begin{array}{c}y=- \\
1115 x+ \\
2822.3\end{array}$ & $\begin{array}{c}y=- \\
2065 x+ \\
2808.7\end{array}$ & $\begin{array}{c}y=- \\
1525 x+ \\
2793.3\end{array}$ & $\begin{array}{c}y=- \\
070 x+ \\
2822.3\end{array}$ & $\begin{array}{c}y=- \\
2455 x+ \\
2787.7\end{array}$ & \\
\hline Mean & $2633 a$ & 2480 bc & $2550 \mathrm{~b}$ & 2640 a & 2406 c & \\
\hline
\end{tabular}

The averages followed by the same letter do not differ statistically between themselves

A significant decrease in seed-yield happened as a result of applying deficit irrigation during flowering, repining and all- stages combined with LSD 82.9 in (AES) and with LSD 26.5 in (WES). 
c- Effect of deficit irrigation levels - on seed yield of wheat crop - at different growth stages (interaction between deficit level and stressed-growth stages):

Interaction between deficit irrigation level and growth stages resulted in significant decrease in seed-yield. This decrease depends on the deficit irrigation level and the stressed growth stage at the same time.

Table (7): wheat grain yield average (Kg /fed) for different stressedgrowing stages under different irrigation deficits compared with non-stressed treatment in (WES) (with sandy soil and sprinkler irrigation).

\begin{tabular}{ccccccc}
\hline \multirow{2}{*}{$\begin{array}{c}\text { Irrigation } \\
\text { deficit }\end{array}$} & $\begin{array}{c}\text { Vegitative } \\
\text { kg/fed }\end{array}$ & $\begin{array}{c}\text { Flowering } \\
\text { kg/fed }\end{array}$ & $\begin{array}{c}\text { Repining } \\
\text { kg/fed }\end{array}$ & $\begin{array}{c}\text { Mature } \\
\text { kg/fed }\end{array}$ & $\begin{array}{c}\text { All } \\
\text { stages } \\
\text { kg/fed }\end{array}$ & Mean \\
\hline $\mathbf{1 0 \%}$ & $1370 \mathrm{aA}$ & $1316 \mathrm{bB}$ & $1348 \mathrm{bAB}$ & $1386 \mathrm{aA}$ & $1297 \mathrm{bB}$ & $\mathbf{1 3 4 3} \mathbf{b}$ \\
\hline $\mathbf{2 0 \%}$ & $1292 \mathrm{bA}$ & $1188 \mathrm{cB}$ & $1270 \mathrm{cA}$ & $1312 \mathrm{bA}$ & $1157 \mathrm{cB}$ & $\mathbf{1 2 4 4} \mathbf{c}$ \\
\hline $\mathbf{3 0 \%}$ & $1222 \mathrm{cAB}$ & $1070 \mathrm{dC}$ & $1184 \mathrm{~dB}$ & $1248 \mathrm{cA}$ & $1014 \mathrm{dD}$ & $\mathbf{1 1 4 8} \mathbf{d}$ \\
\hline $\mathbf{0 \%}$ & $1424 \mathrm{aA}$ & $1424 \mathrm{aA}$ & $1424 \mathrm{aA}$ & $1424 \mathrm{aA}$ & $1424 \mathrm{aA}$ & $\mathbf{1 4 2 4} \mathbf{a}$ \\
\hline & $\mathrm{y}$ & $\mathrm{y}=$ & $\mathrm{y}=$ & $\mathrm{y}=$ & $\mathrm{y}=$ & \\
& $-740 \mathrm{x}+$ & $-1230 \mathrm{x}+$ & $-820 \mathrm{x}+$ & $-690 \mathrm{x}+$ & $-1415 \mathrm{x}$ & \\
& 1442.7 & 1437.3 & 1431.3 & 1453.3 & +1439 & \\
\hline Mean & $\mathbf{1 3 2 7} \mathbf{a b}$ & $\mathbf{1 2 5 0} \mathbf{c}$ & $\mathbf{1 3 0 7} \mathbf{b}$ & $\mathbf{1 3 4 3} \mathbf{a}$ & $\mathbf{1 2 2 3} \mathbf{c}$ & \\
\hline
\end{tabular}

The averages followed by the same letter do not differ statistically between themselves

In (AES), significant decrease in seed-yield happened with flowering stage at deficit level $20 \%$ and $30 \%$. Also, the overall season deficit irrigation treatment shows significant decrease in seed yield at the three studied deficit irrigation levels. Otherwise, either the significant decrease is between the treatments in the same row (deficit level) with no significant decrease between the treatments in the same column (growth stage) and vice versa, or no significant decrease at all.

The least effect of deficit irrigation level in (AES) is shown at 10\% deficit irrigation level at any individual growth stage; as there is no any significant decrease at this level except at the overall season treatment. Furthermore, the least affected growth stage by deficit irrigation is vegetative growth stage and mature stage at all studied levels of deficit irrigation. This trend of data agrees with Ebrahimi Pak (2012). On the 
other hand the trend or order of seed yield disagrees with FAO29 as it's mentioned that vegetative stage is more sensitive than flowering. This difference may be due to the level of applied deficit irrigation or the deficit strategy that was used as it's found by Zhang et al. (2004). These obtained deficiencies in seed-yield may be due to tiller density and kernel density when deficit irrigation is applied during vegetative growth stage. While applying deficit irrigation through flowering stage the decrease in seed yield is due to the reduction happened in number of spikelet per spike or/and number of kernels per spike. Whereas less weight of kernels is scored by applying deficit irrigation throughout the repining or mature stage (Bazza ,1999).

The data of seed yield (WES) indicate a trend like that in (AES); as the flowering stage shows a significant decrease in seed yield at all deficit irrigation levels in both seasons. Moreover, the ripening stage shows significant decrease in seed yield at $20 \%$ and $30 \%$ deficit irrigation level. Additionally, all deficit irrigation levels show significant decrease when it's applied over all growing season.

The minimum effect of deficit irrigation level (without any significant decrease in seed yield) is given by applying $10 \%$ deficit irrigation level at either vegetative or mature stages individually.

\section{Water productivity}

Water productivity (WP) is the grain yield produced per unit volume of water depleted through evapotranspiration (Giriappa 1983). Data given in Tables (8 and 9) show that:

- In (AES), the average WP tends to decrease with increasing water deficit level when applying deficit irrigation during flowering, ripening or mature stage. While applying deficit irrigation during vegetative stage or overall season caused in little increase in WP.

- WP averages tend to decrease with increasing water deficit level; as they are $0.99,0.97$, and $0.95 \mathrm{~kg} / \mathrm{m}^{3}$ for $10 \%, 20 \%$ and $30 \%$ irrigation deficit respectively, compared with 0.98 for non-stressed treatment. This 
may be because the decrease in applied water (achieved through deficit irrigation) is less than the deficiency occurred in seed yield.

\section{Table (8): water use efficiency average $\left(\mathrm{Kg} / \mathrm{m}^{3}\right)$ for different stressed-growing stages under different irrigation deficits compared with non-stressed treatment in clay soil.}

\begin{tabular}{ccccccc}
\hline \multirow{2}{*}{$\begin{array}{c}\text { Irrigation } \\
\text { deficit }\end{array}$} & $\begin{array}{c}\text { Vegetative } \\
\mathbf{k g} / \mathbf{m}^{\mathbf{3}}\end{array}$ & $\begin{array}{c}\text { Flowering } \\
\mathbf{k g} / \mathbf{m}^{\mathbf{3}}\end{array}$ & $\begin{array}{c}\text { Ripening } \\
\mathbf{k g} / \mathbf{m}^{\mathbf{3}}\end{array}$ & $\begin{array}{c}\text { Mature } \\
\mathbf{k g} / \mathbf{m}^{\mathbf{3}}\end{array}$ & $\begin{array}{c}\text { All } \\
\text { stages } \\
\mathbf{k g} / \mathbf{m}^{\mathbf{3}}\end{array}$ & Mean \\
\hline $\mathbf{1 0 \%}$ & 1.02 & 0.95 & 0.97 & 0.99 & 1.01 & $\mathbf{0 . 9 9}$ \\
$\mathbf{2 0 \%}$ & 1.03 & 0.89 & 0.93 & 0.96 & 1.03 & $\mathbf{0 . 9 7}$ \\
$\mathbf{3 0 \%}$ & 1.04 & 0.83 & 0.89 & 0.94 & 1.05 & $\mathbf{0 . 9 5}$ \\
$\mathbf{0 \%}$ & 0.98 & 0.98 & 0.98 & 0.98 & 0.98 & $\mathbf{0 . 9 8}$ \\
Mean & $\mathbf{1 . 0 3}$ & $\mathbf{0 . 8 9}$ & $\mathbf{0 . 9 3}$ & $\mathbf{0 . 9 6}$ & $\mathbf{1 . 0 3}$ & \\
\hline
\end{tabular}

Among the stressed-growing stages, the highest WP value is achieved by applying deficit irrigation overall the growing season or at vegetative stage. On the other hand the lowest WP is given by applying deficit irrigation at flowering stage. It's because, on one hand, applying deficit irrigation overall the season caused a decreasing in seed yield equal or close to that given by applying deficit irrigation during the flowering stage only as shown in tables (6 and 7). On the other hand, the applied water to overall season treatment is less than that applied to stressedflowering stage as displayed in tables (4 and 5).

With less WP values, the data of the (WES) experiment followed a similar trend. As the WP values decreased with increasing deficit irrigation level when it's applied during individual growth stages except vegetative stage. Also, with small difference, WP values, given by applying deficit irrigation throughout either vegetative stage or overall season treatment, surpasses the non-stressed condition.

The results cleared that under conditions of water stress grain yield decreased at a more rapid rate than the degree of decrease in ET rate which resulted in reduction WP

These results disagree with Sewalem et al. (2012) who found that water use efficiency for wheat was higher under dry soil moisture levels than 
wet conditions. May this disagreement subjected to the level of deficit irrigation or the kind of irrigation water. This disagreement maybe due to the difference in length and level of applying deficit irrigation.

Table (9): water use efficiency averages $\left(\mathrm{Kg} / \mathrm{m}^{3}\right)$ for different stressed-growing stages under different irrigation deficits compared with non-stressed treatment in clay soil.

\begin{tabular}{|c|c|c|c|c|c|c|}
\hline \multirow[b]{2}{*}{$\begin{array}{c}\text { Irrigation } \\
\text { deficit }\end{array}$} & \multicolumn{5}{|c|}{ growth stages } & \multirow[b]{2}{*}{ Mean } \\
\hline & $\begin{array}{c}\text { Vegitative } \\
\mathrm{kg} / \mathrm{m}^{3}\end{array}$ & $\begin{array}{c}\text { Flowering } \\
\mathrm{kg} / \mathrm{m}^{3}\end{array}$ & $\begin{array}{c}\text { Repining } \\
\mathrm{kg} / \mathrm{m}^{3}\end{array}$ & $\begin{array}{c}\text { Mature } \\
\mathrm{kg} / \mathrm{m}^{3}\end{array}$ & $\begin{array}{c}\text { All } \\
\text { stages } \\
\mathrm{kg} / \mathrm{m}^{3}\end{array}$ & \\
\hline $10 \%$ & 0.54 & 0.50 & 0.52 & 0.52 & 0.54 & 0.52 \\
\hline $20 \%$ & 0.54 & 0.46 & 0.50 & 0.51 & 0.54 & 0.51 \\
\hline $30 \%$ & 0.54 & 0.42 & 0.47 & 0.49 & 0.54 & 0.49 \\
\hline $\mathbf{0 \%}$ & 0.53 & 0.53 & 0.53 & 0.53 & 0.53 & 0.53 \\
\hline Mean & 0.54 & 0.46 & 0.49 & 0.51 & 0.54 & \\
\hline
\end{tabular}

Yield response factor $(\mathrm{ky})$ to water deficit:

a- Effect of deficit irrigation level on Ky values.

Data illustrated in tables (10) and (11) indicate that the yield response factor to deficit irrigation Ky increases with increasing the deficit irrigation level. In (AES), the Ky values averages are 1.19, 1.76 and 1.95 for deficit irrigation level of $10 \%, 20 \%$ and $30 \%$ respectively. While, they were 2.28, 2.45 and 2.50 for the same treatments in (WES). Furthermore, crop response to deficit irrigation (ky) is higher in (WES) than that in (AES) under the studied conditions. In this conection, Doorenbos and Kassam (1986) reported that seasonal yield response factor of wheat plants was 1.05 and El-Sabbagh (1998) found it 1.83.

\section{b- Effect of stressed-growth stage on Ky values.}

The yield response factor to deficit irrigation Ky is influenced by stressed growing stages. The more sensitive growth stage to deficit irrigation is the higher in Ky values. Crop response to deficit irrigation (ky) according to the different stressed-growth stages is found in the following order flowering > repining > mature> overall season> vegetative in both sits 
under studied conditions. Applying deficit irrigation at flowering stage had the maximum values of (ky) with 4.69 and 3.55 as averages in sandy and clay soil respectively. Whereas, the minimum values were 0.89 and 0.44 scored by applying deficit irrigation during vegetative stage in sandy and clay soil respectively. As the yield response factor to water deficit (ky) is influenced by the losses in wheat yield and the deficit level of irrigation water. In this respect exposing wheat plants to water stress at flowering stage (which indicates low ability of wheat plants to resist water stress) will induce a great yield loss and produce higher value of yield response factor (ky) to water stress than applying deficit irrigation at any other growth stage.

Table (10): Wheat response factor to deficit irrigation averages (ky) for different stressed-growing stages under different irrigation deficits compared with non-stressed treatment in (AES) (with clay soil and surface irrigation).

\begin{tabular}{ccccccc}
\hline \multirow{2}{*}{$\begin{array}{c}\text { Irrigation } \\
\text { deficit }\end{array}$} & \multicolumn{5}{c}{ growth stages } & \\
\cline { 2 - 6 } & Vegetative & flowering & Repining & Mature & $\begin{array}{c}\text { All } \\
\text { stages }\end{array}$ & \\
\hline $\mathbf{1 0 \%}$ & 0.20 & 2.87 & 1.62 & 0.52 & 0.72 & $\mathbf{1 . 1 9}$ \\
$\mathbf{2 0 \%}$ & 0.50 & 3.78 & 2.22 & 1.52 & 0.79 & $\mathbf{1 . 7 6}$ \\
$\mathbf{3 0 \%}$ & 0.63 & 4.01 & 2.37 & 1.92 & 0.84 & $\mathbf{1 . 9 5}$ \\
Mean & $\mathbf{0 . 4 4}$ & $\mathbf{3 . 5 5}$ & $\mathbf{2 . 0 7}$ & $\mathbf{1 . 3 2}$ & $\mathbf{0 . 7 8}$ & \\
\hline
\end{tabular}

c- Effect of deficit irrigation level on Ky values at different stressedgrowth stage (interaction between deficit levels and stressed growth stages).

Applying deficit irrigation with the studied levels at the different growth stages resulted in fluctuations in Ky values. Either at the same deficit level during different growth stages or at the same growth stage with different deficit levels. According to this factor (Ky) the suitable stages to apply deficit irrigation are vegetative and all-stages combined with any of the studied deficit levels in both (AES) and (WES). Also the mature stage may be treated by $10 \%$ deficit level under the conditions of (AES). This suitability is for the reason that the Ky values at these conditions are less than one. 


\section{Straw yield}

Data in tables (12) and (13) indicate that the highest straw yield is achieved under no stress conditions followed by stressed-vegetative stage either in (AES) or (WES) under the studied conditions. On the other hand, the minimum straw yield is scored by overall season deficit irrigation treatment. Additionally, the straw yield is decreased with increasing deficit level.

Table (11): wheat response factor to deficit irrigation averages (ky) for different stressed-growing stages under different irrigation deficits compared with non-stressed treatment in (WES) (with sandy soil and sprinkler irrigation).

\begin{tabular}{ccccccc}
\hline \multirow{2}{*}{$\begin{array}{l}\text { Irrigation } \\
\text { deficit }\end{array}$} & \multicolumn{5}{c}{ growth stages } \\
\cline { 2 - 6 } & Vegitative & flowering & Repining & Mature & $\begin{array}{c}\text { All } \\
\text { stages }\end{array}$ & Mean \\
\hline $\mathbf{1 0} \%$ & 0.77 & 4.44 & 2.66 & 2.61 & 0.90 & $\mathbf{2 . 2 8}$ \\
$\mathbf{2 0 \%}$ & 0.95 & 4.82 & 2.69 & 2.84 & 0.94 & $\mathbf{2 . 4 5}$ \\
$\mathbf{3 0 \%}$ & 0.97 & 4.82 & 2.80 & 2.98 & 0.96 & $\mathbf{2 . 5 0}$ \\
Mean & $\mathbf{0 . 8 9}$ & $\mathbf{4 . 6 9}$ & $\mathbf{2 . 7 2}$ & $\mathbf{2 . 8 1}$ & $\mathbf{0 . 9 3}$ & \\
\hline
\end{tabular}

Table (12): wheat straw yield (ton /fed) for different stressedgrowing stages under different irrigation deficits compared with non-stressed treatment in (AES) (with clay soil and deficit irrigation).

\begin{tabular}{ccccccc}
\hline \multirow{2}{*}{$\begin{array}{c}\text { Irrigation } \\
\text { deficit }\end{array}$} & $\begin{array}{c}\text { Vegitative } \\
\text { Ton/fed }\end{array}$ & $\begin{array}{c}\text { Flowering } \\
\text { Ton/fed }\end{array}$ & $\begin{array}{c}\text { Repining } \\
\text { Ton/fed }\end{array}$ & $\begin{array}{c}\text { Mature } \\
\text { Ton/fed }\end{array}$ & $\begin{array}{c}\text { All } \\
\text { stages } \\
\text { Ton/fed }\end{array}$ & Mean \\
\hline $\mathbf{1 0 \%}$ & 5.8 & 5.3 & 5.4 & 5.6 & 5.2 & $\mathbf{5 . 4}$ \\
$\mathbf{2 0 \%}$ & 5.4 & 4.9 & 5.0 & 5.3 & 4.7 & $\mathbf{5 . 1}$ \\
$\mathbf{3 0 \%}$ & 5.0 & 4.3 & 4.8 & 5.2 & 4.1 & $\mathbf{4 . 7}$ \\
$\mathbf{0 \%}$ & 5.9 & 5.9 & 5.9 & 5.9 & 5.9 & $\mathbf{5 . 9}$ \\
Mean & $\mathbf{5 . 5}$ & $\mathbf{5 . 1}$ & $\mathbf{5 . 3}$ & $\mathbf{5 . 5}$ & $\mathbf{5 . 0}$ & \\
\hline
\end{tabular}


Table (13): Wheat straw yield (ton /fed) for different stressedgrowing stages under different irrigation deficits compared with non-stressed treatment in (WES) (with sandy soil and sprinkler irrigation).

\begin{tabular}{ccccccc}
\hline \multirow{2}{*}{$\begin{array}{c}\text { Irrigation } \\
\text { deficit }\end{array}$} & $\begin{array}{c}\text { Vegetative } \\
\text { Ton/fed }\end{array}$ & $\begin{array}{c}\text { Flowering } \\
\text { Ton/fed }\end{array}$ & $\begin{array}{c}\text { Repining } \\
\text { Ton/fed }\end{array}$ & $\begin{array}{c}\text { Mature } \\
\text { Ton/fed }\end{array}$ & $\begin{array}{c}\text { All } \\
\text { stages } \\
\text { Ton/fed }\end{array}$ & Mean \\
\hline $\mathbf{1 0 \%}$ & 2.9 & 2.7 & 2.8 & 2.9 & 2.7 & $\mathbf{2 . 8}$ \\
$\mathbf{2 0 \%}$ & 2.7 & 2.5 & 2.6 & 2.7 & 2.4 & $\mathbf{2 . 6}$ \\
$\mathbf{3 0 \%}$ & 2.5 & 2.1 & 2.4 & 2.6 & 2.1 & $\mathbf{2 . 3}$ \\
$\mathbf{0 \%}$ & 3.0 & 3.0 & 3.0 & 3.0 & 3.0 & $\mathbf{3 . 0}$ \\
Mean & $\mathbf{2 . 8}$ & $\mathbf{2 . 6}$ & $\mathbf{2 . 7}$ & $\mathbf{2 . 8}$ & $\mathbf{2 . 5}$ & \\
\hline
\end{tabular}

\section{CONCLUSION}

The following conclusions can be drawn:

- The wheat yield performance varied under different water deficit level, soil conditions, water quality and climatic conditions of studied sites.

- Under no shortage condition in irrigation water, the full irrigation is better than deficit irrigation.

- Under the studied conditions of (AES), deficit irrigation may be applied during vegetative or mature stage with level of $10 \%, 20 \%$.

- Also, in (AES), 10\% deficit irrigation may be applied during any individual growth stage. On the other hand, deficit irrigation should be avoided during flowering and ripening stages by $20 \%$ or more.

- In (WES) deficit irrigation may be applied at vegetative or mature stage individually only with $10 \%$.

\section{REFERENCES}

Eid, A. R. and Abuarab, M. E. (2013). Effect of irrigation frequency under hand move lateral and solid set sprinkler irrigation on water 
use efficiency and yield of wheat. Misr Journal of Agric. Eng. 28(4): 217-236.

Bazza, m. (1999). Improving irrigation management practices with water-deficit irrigation. In: Kirda, C., Moutonnet, P., Hera, C., Nielsen, D.R. (Eds.), Crop Yield Response to Deficit Irrigation. Kluwer Academic Publishers, Dordrecht, Boston, London., pp. 21-38.

Debaeke, P.; Aboudrare, A. (2004). Adaptation of crop management to water-limited environments. Eur. J. Agron., 21:433-446

Doorenbos, J.; Kassam, A.H. (1986). Yield response to water. F.A.O irrigation and drainage Paper No. 33.

Duncan, B.D. (1955). Multiple range and multiple F.Test. Biometrics, 11:1- 42.

Ebrahimi Pak N (2012). Determination of Wheat Yield Response Factor to Deficit Irrigation at Different Growth Stages. JCPP., 2 (5):121130.

El- Sabbagh, A.A. (1998). Effect of moisture deficit at different stages on plant growth on wheat production. Menofiya J.Agric. Res., 23(2): 415-426.

English, M.; Nakamura, B. (1989). Effects of deficit irrigation and irrigation frequency on wheat yields. J. Irrig. Drain. Eng., 115(2):172-184.

FAO. 1979. Yield response to water by Doorenbos, J.; Kassam, A. H. . Irrigation and Drainage Paper No. 33. FAO, Rome.

Fereres, E.; Soriano, M.A. (2007). Deficit irrigation for reducing agricultural water use. Special issue on 'Integrated approaches to sustain and improve plant production under drought stress' J. Exp. Bot., 58:147-159. 
Giriappa, S. (1983). Water use efficiency in agriculture. Oxford \& IBH publishing C.O. New Delhi.

Howell, T. (2001). Enhancing water use efficiency in irrigated agriculture. Agron. J., 93:281-189.

Kirda, C.; Kanber, R.; Tu“ lu“ cu“, K.; Gu“ ngo“ r, H. (1999). Yield response of cotton, maize, soybean, sugar beet, sunflower and wheat to deficit irrigation. In: Kirda, C., Moutonnet, P., Hera, C., Nielsen, D.R. (Eds.), Crop Yield Response to Deficit Irrigation. Kluwer Academic Publishers, Dordrecht, Boston, London., pp. 21-38.

Klute, A. (1986). Methods of Soil Analysis Part I. Physical and mineralogical Methods. $2^{\text {nd }}$ ed., Agron. Madison, Wisconsin, U.S.A.

Liu, H.; Yu, L.; YuLuo; Wang, X; Huang, G. (2011). Responses of winter wheat (Triticum aestivum L.) evapotranspiration and yield to sprinkler irrigation regimes. Agricultural Water Management, 98:483-492

Madanoglu, K. (1997). Water consumption of wheat (Yektay 406) in central Anatolia. Ankara. Ankara Central TOPRAKSU Research Institute. Publication No. 52:67.

Mugabe, F.T.; Nyakatawa, E.Z. (2000). Effect of deficit irrigation on wheat and opportunities of growing wheat on residual soil moisture in southeast Zimbabwe. Agric. Water Manage., 46:111119.

MOALR (Ministry of Agriculture and land reclamation), Egypt 2000, 2002 "Tillage and agriculture of Zea maize ", Polletin No. 734. 
Singh SD (1981). Moisture sensitive growth stages of dwarf wheat and optimal sequencing of Evapo-transpiration Deficits. Agron J., 73(3):387-391.

Smith, M. (1992). CROPWAT a computer program for irrigation planning and management. Irri. \& Drain. Paper, No. 46, FAO, Rome, Italy.

Snedecor, G. W; Cochran, W. G. (1980). "Statistical Methods". $7^{\text {th }}$ Ed.Iowa, State Univ.Press, Ames.Iowa, U.S.A. PP: 593.

Zhang, H.; Oweis, T., 1999. Water-yield relations and optimal irrigation scheduling of wheat in the Mediterranean region. Agr. Water Manage., 38:195-211.

Zhang, Y.; Kendy, E.; Qiang, Y.; Changming, L.; Yanjun, S.; Hongyong, S. (2004). Effect of soil water deficit on evapotranspiration, crop yield, and water use efficiency in the North China Plain. Agric. Water Manage., 64:107-122.

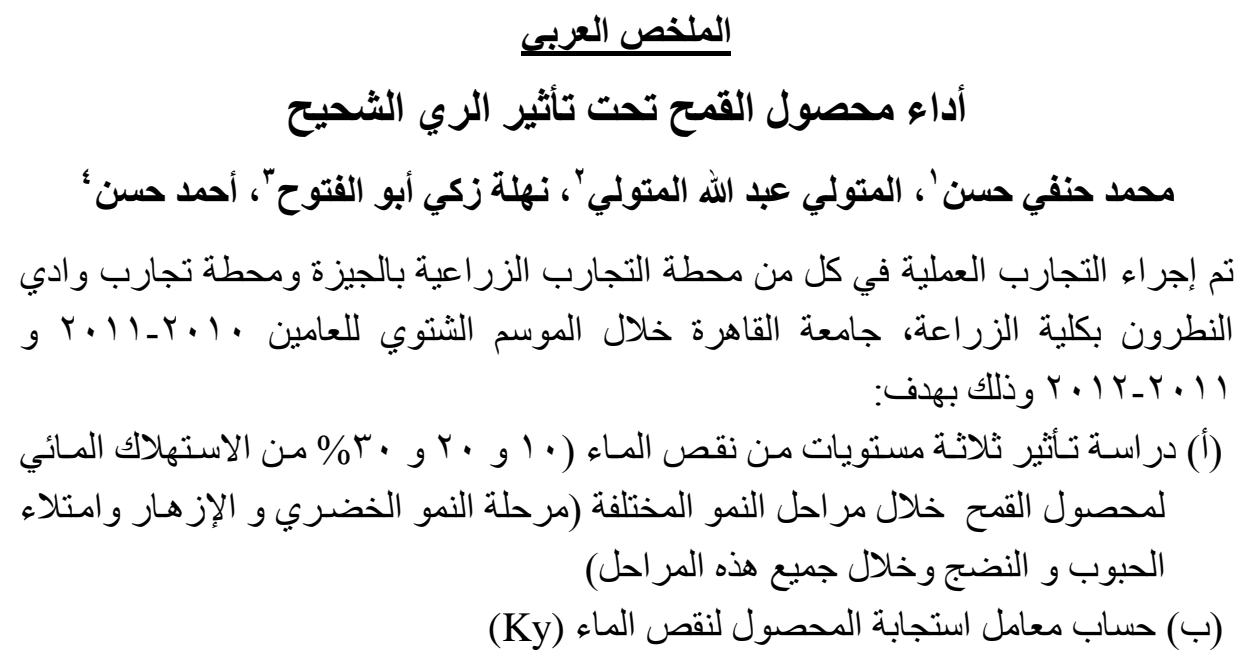

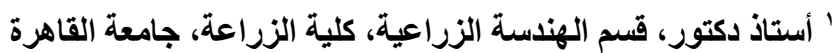

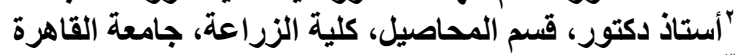

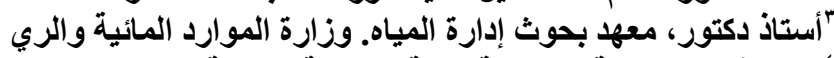

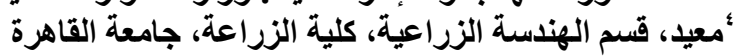


(ج) در اسة تأثنير نقص الماء على انتاجية ماء الري. وبناءً على نتائج التجارب وُجد أن إمداد محصول القمح بكل احتياجاته من مياه الري أنتج أعلى

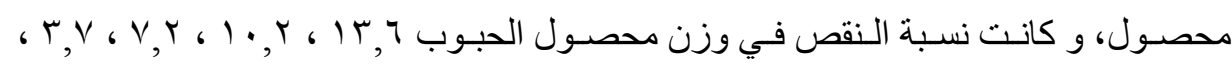

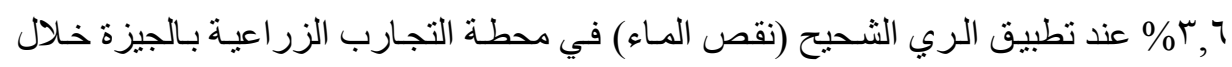

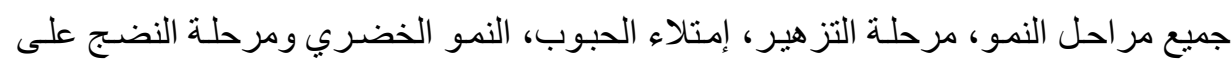

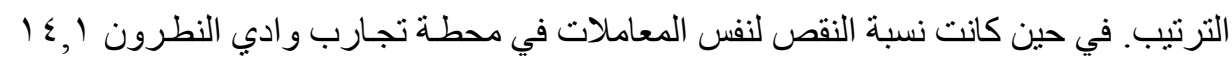

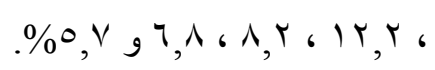

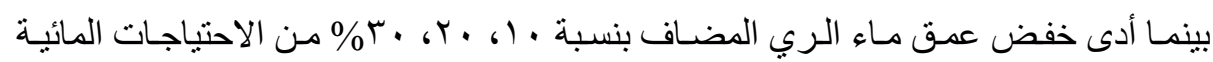

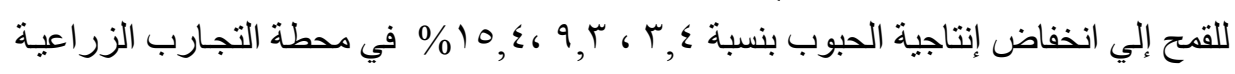

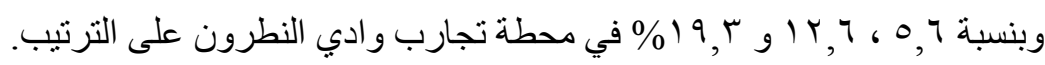

ز ادت قيمـة معامـل استجابة المحصـول لنقص المـاء (Ky) بزيـادة مستوى نقص المساء. و عنـــ خفض عمـق ميـاه الري المضـافة خـلال مر احل النمـو المختلفة؛ وُجد أن قيم معامـل اسـتجابة المحصـول لنقص المـاء (Ky) اتخذت الترتيب الآتـي: الإزهـار > مرحلـة امـتلاء الحبـوب > مرحلة النضج > جميع مر احل النمو> مرحلة النمو الخضري تحت ظروف الدر اسـة. في حين تأثرت إنتاجية وحدة مياه الري بشكل ضئيل تحت ظروف الري المختلفة. 